\title{
MARCAS IDENTITÁRIAS EM CARTAS DE DETENTAS: SILENCIAMENTO OU RESISTÊNCIA AO PODER?
}

\author{
IDENTITY MARKS IN INMATES' LETTERS: SILENCING OR RESISTENCE TO POWER?
}

\author{
Daniele Cristina Scaliante \\ UFMS - CPTL
}

\section{Celina Aparecida Garcia de Souza Nascimento}

UFMS - CPTL

\begin{abstract}
RESUMO: O objetivo deste trabalho ${ }^{1}$ é apontar as relações de poder, silenciamento e exclusão na escrita de cartas de detentas do Presídio Feminino de Três Lagoas - MS, interpretando pelas marcas de subjetividade as representações identitárias construídas no/pelo olhar do outro. Para tanto, partimos da hipótese de que embora haja o silenciamento, discursos da resistência e/ou da estratégia emergem em confronto com representações identitárias de exclusão. Como procedimento metodológico, selecionamos excertos de cartas escritas por detentas do Presídio Feminino de Três Lagoas - MS a familiares, amigos ou ao companheiro (marido). O arcabouço teórico deste trabalho fundamenta-se na Análise do Discurso de linha francesa e, principalmente, nas contribuições de Hall $(2005)$ e Coracini $(2003,2007)$ sobre identidade, em Orlandi (2007) sobre as significações do silêncio, e, ainda, nos pressupostos do filósofo Michel Foucault (1979, 1995, 2006a, 2012) sobre as relações de poder, disciplina e discurso. A análise indica que em confronto às representações identitárias que supõem que as detentas sejam reguladas, silenciadas e submissas ao sistema de controle, emergem discursos que caracterizam esse contexto de privação da liberdade enquanto um espaço de luta e sobrevivência, uma vez que essas mulheres se representam como "sobreviventes" e "fortes" na tentativa de desconstruir representações excludentes.
\end{abstract}

PALAVRAS-CHAVE: Análise do Discurso; identidade; poder; exclusão.

ABSTRACT: The objective of this paper is to show the relations of power, silencing and exclusion in writing letters of a Female Prison inTrês Lagoas - MS, interpreting the marks of subjectivity and the identity representations built in/ for the other's gaze. For that reason, we started from the assumption that although there is silencing and there are resistence and/or strategy speeches, they emerge in confrontation with identity representations of exclusion. As a methodological procedure, we selected excerpts from letters written by inmates of the Female Prison in Três Lagoas - MS which were sen to their family, friends or husbands. The theoretical outline of this paper is based on the Analysis of the French Discourse and mainly on Hall's contributions (2005) and also Coracini's $(2003,2007)$ about identity, on Orlandi's (2007) about the meaning of silencing and also on the assumptions of the philosopher Michel Foucault (1979, 1995, 2006a, 2012) about the relations of power, discipline and speech. The analysis indicates that in comparison to identity representations which assume that the inmates are regulated,

\footnotetext{
${ }^{1}$ Este trabalho apresenta resultados parciais da pesquisa de Mestrado desenvolvida sob a orientação da Prof. ${ }^{a}$ Dra. Celina Ap. G. S. Nascimento, vinculada ao projeto de pesquisa: "Linguagem, discurso e identidade de adolescentes e adultos em situação de exclusão: escrita de si” e ao Grupo Vozes (In)fames: exclusão e resistência/UNICAMP.
} 


\section{Revista do SELL \\ v. $4, n^{\circ} .1$ \\ ISSN: $1983-3873$}

silenced and submissive to the control system, discourses emerge and they characterize that context of deprivation of liberty as a space of struggle and survival, since those women represent themselves as "survivors" and "strong" in an attempt to deconstruct exclusive representations.

KEYWORDS: Analysis of the speech; identity; power; exclusion.

\section{Introdução}

Perpassadas por concepções imaginárias, as representações que compõem os discursos cristalizados em sociedade acerca dos sistemas prisionais são atravessadas pelas relações de poder, que por vezes, delegam aos referidos sistemas o controle e a disciplina. Entretanto, a subjetividade constitui os sujeitos que ocupam esse espaço de privação de liberdade, e, em seu discurso, sentidos silenciados vêm à baila, bem como confrontos acerca de representações identitárias que emergem uma possível situação de exclusão na qual se veem e pela qual se representam.

Nesse tocante, o objetivo deste trabalho é apontar as relações de poder, silenciamento e exclusão na escrita de cartas de detentas do Presídio Feminino de Três Lagoas - MS pelas marcas de subjetividade nelas deixadas, interpretando as representações que essas mulheres fazem de si no/pelo olhar do outro, a fim de compreender como se representam nesse contexto de privação de liberdade. Para tanto, partimos da hipótese de que embora haja o silenciamento, discursos da resistência e/ou da estratégia emergem em confronto com representações identitárias que se constituem no/pelo olhar do outro, uma vez que as mulheres detentas, ao escreverem suas cartas, passam por um processo de exposição de sua subjetividade, por serem essas, lidas pela direção do Presídio.

Refletir acerca das representações de identidade de detentas considerando as condições de produção em que seus discursos emergem é subsídio para este trabalho, que é norteado pelas seguintes indagações: visando as relações de poder-saber que constituem esse processo de (des)construção das representações identitárias, quais discursos emergem nesse contexto? Serão as detentas "condenadas" ao silenciamento que atravessa seu discurso? Como se representam nesse contexto?

Nesse sentido, a Lei de Execução Penal de 1984 (BRASIL, 2009) em seu artigo 1은 prevê: "A execução penal tem por objetivo efetivar as disposições de sentença ou decisão criminal e proporcionar condições para a harmônica integração social do condenado e do internado". Entretanto, na contramão desse objetivo estipulado em lei, o que se observa 


\section{Revista do SELL}

v. $4, n^{\circ} .1$

ISSN: $1983-3873$

nos noticiários são os inúmeros casos de reincidências criminais, fugas, rebeliões e aumento no número de crimes, fatores esses que alarmam uma possível situação de exclusão. Isso porque, ao serem privados da liberdade para uma suposta transformação, esses sujeitos são retirados do convívio em sociedade e, ao retornarem ao convívio social são considerados sujeitos "pós-crime", sendo constitutivamente marcados no/pelo discurso do outro e, sobretudo, pela memória que a prisão carrega. Nesse tocante, as relações de poder atravessam os discursos cristalizados que "fabricam sujeitos" (FOUCAULT, 2010b, p. 38).

Assim, enquanto o sistema prisional propõe a recuperação e transformação de sujeitos considerados criminosos porque não cumpriram as regras existentes na sociedade e estipuladas em lei, ficam esses, no entanto, após sua passagem pela prisão, marcados indelevelmente com representações atribuídas pelo outro. Nesse sentido, por meio de discursos que circulam em sociedade há representações que corroboram para o descaso e, sobretudo, exclusão daqueles que são condenados não pelo tempo determinado de sua sentença, mas por sentidos cristalizados que os excluem durante e depois do cumprimento de suas penas.

Considerando esse cenário brevemente apresentado enquanto constituinte deste trabalho, partimos da necessidade de investigar a relação sujeito excluído, sociedade e Instituição, uma vez que as relações de poder atravessam o discurso desses sujeitos em privação de liberdade e constituem sua subjetividade pelas formações discursivas e ideológicas. Além disso, há a necessidade de tratar de dizeres de mulheres detentas por se encontrarem em situação de exclusão, "dando voz" (ou ouvindo sua voz?) a elas.

O arcabouço teórico deste trabalho fundamenta-se na Análise do Discurso de linha francesa e, principalmente, nas contribuições de Hall (2005) e Coracini (2007) sobre identidade, em Orlandi (2007) sobre as significações do silêncio, e, ainda, nos pressupostos do filósofo Michel Foucault $(1979,1995,2006 a, 2012)$ sobre as relações de poder, disciplina e discurso.

Como procedimento metodológico, selecionamos para a análise excertos de cartas $^{2}$ escritas por detentas do Presídio Feminino de Três Lagoas - MS, normalmente em seu dia-a-dia, com destino a familiares, amigos ou o companheiro (marido) que por vezes possa estar no Presídio Masculino. Essas cartas passam sempre pelo crivo do regimento da Instituição. Assim, qualquer carta escrita nesse espaço, bem como as que

\footnotetext{
${ }^{2}$ Estas cartas foram selecionadas do corpus que constitui a pesquisa de Mestrado já citada, que possui um totalizante de cinquenta e oito cartas coletadas e seguem a denominação utilizada na referida pesquisa (Carta 1, carta 2, carta 3...).
} 


\section{Revista do SELL}

v. $4, n^{\circ} .1$

ISSN: $1983-3873$

chegam destinadas às mulheres detentas é lida por dirigentes responsáveis por este procedimento, que verificam se há na escrita o cumprimento dos critérios que estabelecem para a autorização de envio e recebimento de cartas.

Assim, este artigo está dividido em duas partes: na primeira, há uma breve discussão teórica e a segunda, traz a análise dos recortes das cartas.

\section{Mapeando alguns conceitos: discurso, identidade e relações de poder}

Nesse momento, trataremos dos conceitos que subsidiam este trabalho, em especial, das noções de discurso, identidade e relações de poder, uma vez que interessanos refletir de que modo as mulheres detentas se representam no/pelo olhar do outro em privação de liberdade, bem como, quais discursos emergem na escrita de suas cartas.

Para tanto, partimos do conceito foucaultiano de discurso, em que: "o discurso não é simplesmente aquilo que traduz as lutas ou os sistemas de dominação, mas aquilo por que; pelo que se luta, o poder do qual nos queremos apoderar" (FOUCAULT, 1995, p.10). Assim, por essa noção de discurso é que consideramos que o sujeito ocupa diferentes posições em distintos espaços e momentos históricos, o que nos permite considerar que o lugar de onde fala também constitui o seu discurso, que se dá numa arena de luta.

Por isso, ao analisarmos quais os discursos emergem na escrita das cartas das mulheres detentas e quais efeitos de sentido produzem nesse contexto, consideramos que estes se travam enquanto instrumento de poder. Ainda, o discurso é atravessado por formações discursivas e ideológicas que o constituem, e nesse caso, vale ressaltar que o discurso das mulheres detentas é perpassado pelo controle e pela disciplina, que buscam transformar e corrigir esses sujeitos considerados enquanto errantes perante a lei e a sociedade. Assim, ao investigarmos por meio da escrita das cartas as regularidades discursivas existentes, o confronto e as tensões emergem no discurso enquanto possível forma de resistência e/ou estratégia em meio às relações de poder, conforme observado na segunda parte deste trabalho.

Sob tais veredas, há que se considerar ainda, que o sujeito, inscrito em um dado momento histórico e regido por leis e determinações (nem sempre jurídicas, mas de cunho social, político e ideológico) produz seu discurso pautado no que pode e deve ser dito. Nesse tocante, esses espaços limitados que se dão nas formações discursivas e ideológicas simulam uma ilusória propriedade, pois permanecendo poder-saber interligados no jogo discursivo é que se constitui a trama dessa relação, uma vez que o 


\section{Revista do SELL}

v. $4, n^{\circ} .1$

ISSN: $1983-3873$

sujeito, validado pelo poder a ele atribuído no/pelo discurso, pode também silenciar. Nesse caso, reveste-se de valor o seu silêncio, pois segundo Orlandi (2007, p.31) "o silêncio é. Ele significa. Ou melhor: no silêncio, o sentido é".

Além disso, consideramos neste trabalho a questão da identidade enquanto inacabada, construída no/pelo olhar do outro. Assim, pois, por meio dessa perspectiva a (tentativa de) transparência que pressupõe a questão identitária enquanto acabada e/ou estável desloca-se por meio de efeitos de sentido que confrontam tal pressuposto, pois esta é tida em constante processo, sendo multifacetada, atravessada pelo imaginário social, passível de mudanças e deslocamentos. Partimos então, da seguinte noção de identidade:

A identidade é realmente algo formado, ao longo do tempo, através de processos inconscientes, e não algo inato, existente na consciência no momento do nascimento. Existe sempre algo "imaginário" ou fantasiado sobre sua unidade. Ela permanece sempre incompleta, está sempre "em processo", sempre "sendo formada". (HALL, 2005. p.38)

Logo, perpassam a questão da identidade significações e representações advindas de diferentes lugares e sujeitos, sendo esses imersos em um dado contexto e momento sócio-histórico. Nesse tocante, a identidade se constitui em constante (des)construção, pois nesse processo, ela é deslocada por múltiplas identificações que o sujeito faz com o outro. Na esteira do que diz Coracini (2007, p.49) "não há identidade possível a não ser na ilusão, na promessa sempre adiada da coincidência consigo mesmo, do pertencimento imaginado (e inventado) a uma nação, a um grupo [...]". Assim, consideremos que por meio das representações de identidade que as detentas emergem em seu discurso, que por sua vez é atravessado pela disciplina, vigilância e poder, diferentes efeitos de sentido caracterizam uma possível situação de exclusão. Isso porque, ao se representarem no/pelo olhar do outro, as mulheres deixam marcas em sua escrita que são perpassadas pelo imaginário social acerca de sua representação, que por vezes, é excludente, pois não as consideram pertencentes à sociedade.

Nesse ponto, representações cristalizadas corroboram para que esses sujeitos em privação de liberdade sejam vistos e representados pela homogeneização, e nesta, há uma tentativa de manipulação do poder, saberes e ideologias. Entretanto, considerando que partiremos nesse momento dos pressupostos foucaultianos no que diz respeito às relações de poder, esclarecemos que perspectivas que consideram prioritariamente a relação de assujeitamento e legitimam a dicotomia "opressor versus oprimido" não 


\section{Revista do SELL}

v. $4, n^{\circ} .1$

ISSN: $1983-3873$

constituem este trabalho, pois segundo reflete Foucault (1979) o poder está em toda a parte, em lutas cotidianas, não em locais específicos (Instituições, pessoas). Além disso, se tal relação de opressão fosse consolidada, o poder seria apenas visto por um viés, sem analisar sua mecânica e o fato de penetrar nas tramas da sociedade.

Assim, mediante tal embasamento sobre as relações de poder, o pressuposto foucaultiano considera que ele se dá a partir de disseminações sociais, ou seja, não o prevê enquanto estável e centralizado, o que nos permite relacioná-lo a este trabalho, em que por meio dos discursos das mulheres detentas o poder circula enquanto prática social.

Nesse tocante, passemos agora à análise dos recortes selecionados das cartas escritas pelas mulheres detentas.

\section{Análise das cartas: a prisão como lugar de exclusão}

Por questão metodológica, trazemos aqui uma breve discussão acerca da noção de lugar, uma vez que, como trataremos na análise, esta questão constitui uma regularidade no discurso das mulheres detentas em suas cartas. Assim, a respeito da noção de "espaço como lugar", cabe fazer da nossa, a mesma preocupação de Reis (2011) que, ao investigar em seu doutoramento o ensino-aprendizagem do inglês em uma Unidade Socioeducativa para adolescentes infratores, compreende que a relação que se dá entre o espaço e a memória que atravessa os dizeres e ações dos sujeitos de sua pesquisa é primordial para analisar os discursos.

Assim, consideramos que a memória constitui o discurso das mulheres detentas e, no caso deste trabalho, tem relação não estritamente aos limites da cela que esses sujeitos ocupam, nem tão somente à Instituição Presídio, mas aos efeitos de sentido que atravessam seu discurso, uma vez que este é perpassado pelo lugar de onde falam, que passa a lhes representar. Logo, a nomeação dessas mulheres como "internas", "presas", "detentas", entre outras, carrega sentidos que vão além de referências nominais, pois são atribuídas pelo lugar que esses sujeitos ocupam em sociedade.

Entre outros pontos que Reis (2011) aborda na referida questão, compartilharemos, em especial, do momento em que a pesquisadora parte do conceito desenvolvido por Foucault (2012) acerca da noção de espaço. A esse respeito, Foucault (2012, p. 188) diz que no século XIX, a lepra suscitou modelos de exclusão, onde aos leprosos foi aplicado um espaço excludente; já a peste, suscitou esquemas disciplinares. O filósofo explica que 


\title{
Revista do SELL
}

v. $4, n^{\circ} .1$

ISSN: $1983-3873$

ao tratar os leprosos como pestilentos, os processos de individualização marcavam exclusões, e ainda, o poder disciplinar regularizou desde o começo desse século, o asilo psiquiátrico, a penitenciária, a casa de correção, o estabelecimento de educação vigiada, entre outros.

Nesse sentido, essas Instituições funcionaram duplamente, isto é, pela "divisão binária e da marcação (louco-não louco; perigoso-inofensivo; normal-anormal)" (FOUCAULT, 2012, p. 189), bem como pela "determinação coercitiva, da repartição referencial (quem ele é; onde deve estar; como caracterizá-lo, como reconhecê-lo; como exercer poder sobre ele, de maneira individual, uma vigilância constante, etc) (p. 189)". Esses controles disciplinares fizeram funcionar os mecanismos dualistas da exclusão. Assim, as regularidades discursivas que apontam a prisão como um lugar de exclusão são atravessadas pelo já-dito, que traz à baila o sentido de que nesse espaço encontramse sujeitos privados de liberdade porque são considerados anormais, e que, sobretudo, precisam ser corrigidos e transformados.

É nesse tocante que trataremos da noção de lugar na análise a seguir, que traz dois recortes selecionados da escrita de cartas de mulheres detentas do Presídio Feminino de Três Lagoas - MS:

\begin{abstract}
Recorte (1):
[...] Eu estou indo daquele jeito, mas estou bem na medida do possível, no lugar que me encontro não tenho motivos para estar feliz só me sinto bem quando chega carta sua e quando falo com a Senhora, mãe você poderia mandar mais carta se você soubesse como cartas são importantes para quem está presa uma carta é o mesmo que uma visita nos sentimos lembrados me escreve por favor sei que não meresso por tudo que já te fiz mas tenha piedade apesar de tudo sou sua filha e te amo muito; errar é humano ${ }^{3}$ não sou perfeita sou cheia de defeitos mas sou um serumano tenho esse lado podre meu, mas ninguém melhor que você mãe para saber que sou uma pessoa do bem se estou nesse lugar hoje foi para ajudar uma pessoa que não merecia o meu maior defeito é gostar de quem não presta mas não mandamos no coração se Deus quis assim quem sou eu para questionar tudo tem um por que nada acontece por acazo né [...] como me sinto triste sozinha longe de vocês, longe de casa aqui onde estou é muito triste nem tem como explicar, é muito sofrimento envolvido mas logo logo este sofrimento acaba sairei daqui outra pessoa a cadeia nos ensina a lei da sobrevivência só os fortes permanecem os fracos são maçacrados mãe aqui é onde o filho chora e a mãe não vê [...] quando sair daqui prometo ser uma mãe melhor [...] agora lhe escrevendo estou chorando queria tanto ser livre estar aí e poder dizer tudo isso pessoalmente mas no momento é impossível.
\end{abstract}

(Carta 1)

\footnotetext{
${ }^{3}$ Nas páginas da carta (que são quatro) há recados, frases e pensamentos nas laterais da folha. Em um deles, na primeira página consta: "Vê se não faz nada de errado para não ter o mesmo destino meu".
} 


\section{Revista do SELL}

v. $4, n^{\circ} .1$

ISSN: $1983-3873$

No contexto em que se insere o dêitico "daquele", acompanhando o substantivo masculino "jeito", emerge o sentido de que o sujeito deseja, pela escrita, mostrar o estado (emocional ou corporal) pelo qual se vê, e para isso, refere-se a uma representação em particular, o que mais adiante é confirmado pela expressão "na medida do possível". Foucault (2006b, p. 157) atenta para o fato de que a escrita possibilita uma "relação consigo", e destaca que nela é possível encontrar um dos seus privilegiados elementos: "as interferências da alma e do corpo (as impressões mais do que as ações)". Nesse tocante, emerge no discurso o sentido de que o sujeito busca sua completude, o desejo de estar bem, e nesse caso, não descreve como está, e ainda, ao referir-se pelo dêitico "daquele", produz o sentido de que o destinatário sabe que jeito é esse.

Entretanto, "esse dizer não é óbvio" (AUTHIER-REVUZ, 1998, p. 26), e assim, ao escrever que está indo "daquele jeito", o sujeito busca definir seu estado de espírito por uma referência a um signo linguístico que lhe assegure a unicidade de sentido, a possibilidade de expressar por uma palavra, seus sentimentos. Contudo, ao mesmo tempo em que busca especificá-los, "aguça a tensão entre o um e o não-um" (p. 26), pois as palavras vêm carregadas de sentidos, e, ao colocar: "mas estou bem na medida do possível", a conjunção adversativa "mas" corrobora para o sentido inicial de que não está "mal", pois descreve-se pelo advérbio de modo "bem". Em seguida, porém, seu "bemestar" é comprometido pelo "lugar" em que está: "no lugar que me encontro não tenho motivos para estar feliz". Assim, a preposição "no", seguida do substantivo masculino "lugar" associa a prisão e sua posição de mulher presidiária enquanto motivos de sua tristeza, pois a partícula negativa "não" contraria a afirmação de estar bem, produzindo o efeito de sentido que esse lugar (representado pela Instituição Presídio) Ihe impede de ser feliz e, nesse dizer, o sujeito se representa como uma pessoa infeliz.

Nesse sentido, o uso do advérbio de exclusão "só" condiciona o seu bem-estar ao lugar do qual se vê, como em: "só me sinto bem quando chega carta sua e quando falo com a Senhora". Nesse caso, pelo condicionamento produzido pelo uso do "só", emerge nesse discurso o que Foucault (2006b, p. 158) relata acerca da escrita de si: "às vezes, trata-se também de lembrar os efeitos do corpo na alma, a ação desta no corpo, ou a cura do primeiro pelos cuidados dispensados à segunda". Esse condicionamento pelo recebimento da carta produz o efeito de sentido de que, pela escrita, o sujeito pode apaziguar a tristeza que afeta a sua alma pelo lugar que ocupa, precisando escrever, ler e ser lido, para que assim, possa diminuir na alma, os efeitos causados pelo seu corpo, que está preso. Pela escrita, o sujeito pode se sentir completo. 


\section{Revista do SELL}

v. $4, n^{\circ} .1$

ISSN: $1983-3873$

Nos dizeres: "mãe você poderia mandar mais carta se você soubesse como cartas são importantes para quem está presa", "uma carta é o mesmo que uma visita nos sentimos lembrados" e "me escreve por favor", há pela escrita, o desejo do encontro consigo e com o outro, emergindo o valor que a carta possui. Nesse sentido, Skliar (2008, p. 23), ancorado no que diz Derrida, reflete sobre "a relação que se dá entre a vida de um texto, a sobrevivência e a não sobrevivência do texto". Assim, as cartas, se não respondidas, não sobrevivem. Para também "sobreviver", o sujeito precisa ser respondido. Isso porque, ao escrever, olha para si, mas o faz também sob os olhos do outro, e quando correspondido, se sente "importante", "visitado" e "lembrado". Nesse caso, o substantivo masculino "mesmo", atribui à carta a responsabilidade de possibilitar tais sentimentos. Logo, a escrita permite que o sujeito olhe para suas próprias sensações, sentimentos e estado de sua alma. Esses dizeres se referem a apelos feitos pelo sujeito, a fim de que 0 outro lhe escreva.

Assim, no primeiro dizer, o verbo "poder", no futuro do pretérito, sugere uma possibilidade de correspondência. A expressão "você poderia", segundo Authier-Revuz (1998, p. 61), "vem da modalidade deôntica da permissão - quase exclusivamente via o auxiliar modal poder". Logo, pedir permissão ao outro para que seja correspondido, "é pedir e oferecer hospitalidade" (SKLIAR, 2008, p. 57), pois escrever carta "é promover encontro com o outro" (p. 57). Em seguida, no segundo dizer, emerge uma tentativa de convencimento, onde pelo uso do "se", sugere que há motivos que o outro precisa saber para que the escreva: a importância que tem a carta na prisão. Pelo verbo "saber", conjugado no pretérito imperfeito do subjuntivo, produz o sentido de que é necessário que o outro saiba dessa importância para que possa lhe escrever; ainda, pelo uso do "como", busca atribuir com intensidade a importância à carta.

Sobre o efeito de sentido da expressão "para quem está presa", a utilização do pronome relativo "quem", engloba nesse caso, todas as mulheres que se encontram na mesma situação, ou seja, emerge a presença do outro no seu discurso, pois "o sujeito é também alteridade, carrega em si o outro, o estranho, que o transforma e é transformado por ele" (CORACINI, 2007, p.17). Logo, esse sujeito fala não somente por ele, mas por um conjunto de sujeitos vistos pela mesma situação, e o faz no desejo de identificar-se com o outro, pertencer a um grupo, ser pertença, sentido que se dá também em: "nos sentimos lembrados". Nessa frase, em primeira pessoa do plural, o pronome pessoal "nos" inclui o sujeito que escreve, bem como um grupo específico: a população presidiária. É nesse sentido que Coracini (2007, p. 50) faz também uma referência à 


\section{Revista do SELL}

v. $4, n^{\circ} .1$

ISSN: $1983-3873$

questão da identidade abordada por Derrida, que a vê como um sentimento de pertença "a um grupo, a uma nação, a uma etnia, a uma religião, enfim, pertença à língua e da língua, pertença sempre marcada pela e na historicidade, inscrição do sujeito que se faz no espaço e no tempo, admitida, permitida ou coibida pelo outro".

Esse sentimento de pertença presente no discurso produz ainda outros sentidos, pois, ao dizer que essa situação não acontece somente com ela, mas com todas as mulheres que fazem parte desse cenário de privação de liberdade inclui também questões sociais de exclusão, porque denuncia uma solidão que não é somente individual, mas coletiva. A esse respeito, Sawaia (2001, p. 9) discute acerca da "dialética exclusão/inclusão", dizendo que "a exclusão é processo complexo e multifacetado, uma configuração de dimensões materiais, políticas, relacionais e subjetivas". Diz ainda a autora, que esse é um processo sutil e dialético, que só existe em relação à inclusão, pois a exclusão é sua parte constitutiva, e assim: "não é uma coisa ou um estado, é processo que envolve o homem por inteiro e suas relações com os outros" (p. 9).

Assim, ao ver-se enquanto "mulher presa" o sujeito buscar identificar-se a um grupo, incluir o outro no seu discurso, produzindo o efeito de sentido de que pelas práticas punitivas, bem como pela Lei, representada na/pela "Instituição Presídio", que tem a função de retirar o "sujeito criminoso" do convívio para posteriormente "incluí-lo" na sociedade, é que se dá a exclusão, uma vez que ao olhar para si pelo olhar do outro, o sujeito que escreve emerge as representações identitárias das quais busca distanciar-se, e identifica-se a outras, pelas quais deseja ser olhado. Logo, esse discurso produz o sentido de que a prisão, na tentativa de incluí-lo a um grupo social, que é a sociedade, todavia o exclui, pois para que se inclua, é necessário que se esteja excluído.

Ainda, em: "sairei daqui outra pessoa a cadeia nos ensina a lei da sobrevivência", há marcas linguísticas que apontam para uma transformação do sujeito: o verbo "sair", no futuro do presente e o dêitico "daqui" marcam o fim do cumprimento da pena e sua saída da prisão; o pronome indefinido "outra" e o substantivo feminino "pessoa" produzem o sentido de correção; o verbo "ensinar", que também significa castigar, reforça esse sentido de "indivíduo corrigido". Assim, esses dizeres são atravessados por uma visão de prisão enquanto lugar de correção, citada por Foucault (2012, p. 123): "não se pune portanto para apagar um crime, mas para transformar um culpado [...] o castigo deve levar em si uma certa técnica corretiva".

Nesse dizer, o substantivo feminino "lei" vem da formação discursiva jurídica, emergindo as questões da obediência, do cumprimento, da seriedade, da obrigatoriedade, 


\section{Revista do SELL}

v. $4, n^{\circ} .1$

ISSN: $1983-3873$

trazendo a ideologia de que tudo o que é lei, deve ser cumprido. Assim, esse dizer: "lei da sobrevivência”“ emerge o discurso de luta, e nesse caso, por estar presa, não é regida somente pela lei que a condena, mas também por relações de poder que se dão entre as internas, numa espécie de competição, como diz em: "só os fortes permanecem os fracos são massacrados". Nesse sentido, "o poder não está, substancialmente, identificado a um indivíduo que o possuiria e o exerceria desde sua origem; ele torna-se um maquinário do qual ninguém é titular" (FOUCAULT, 2010a, p. 117).

No dizer: "aqui é onde o filho chora e a mãe não vê", pelo dêitico "aqui", bem como pelo sentido cristalizado dessa frase, refere-se à prisão ${ }^{5}$. Assim, os substantivos "filho" e "mãe", bem como o verbo "chorar" produzem um efeito de sentido que define a prisão enquanto um lugar de sofrimento, pois significa que o sujeito que comete um crime é punido, e estando na prisão, ninguém pode protegê-lo. O verbo "ver" produz o sentido de que esse sofrimento não é visto pelos outros e coloca os sujeitos numa situação de controle, pois os muros os afastam da sociedade, sendo vigiados e disciplinados; esse sentido de sofrimento também se dá no dizer "é muito sofrimento envolvido". Entretanto, o poder continua circulando, pois "o poder não é a disciplina; a disciplina é um procedimento possível do poder" (FOUCAULT, 2006c, p. 224).

O ato de "prometer" ser uma nova mãe emerge o comprometimento, o juramento do que vai fazer ou dizer. Nesse caso, pelo discurso jurídico, o juramento em meio às práticas dos tribunais, postula(va) que os réus, colocados para julgamento, deveriam dizer cristalizado "juro dizer a verdade, somente a verdade, nada mais que a verdade". Assim, esse interdiscurso sugere a questão da verdade, pois esse sujeito, objetivado como um sujeito criminoso busca constituir-se pela sua verdade. Cabe acrescentar aqui, a esse respeito, uma reflexão de Foucault (2006c, p. 280): "Por que nos preocupamos com a verdade, aliás, mais do que conosco? E por que somente cuidamos de nós mesmos através da preocupação com a verdade?". Nesse sentido, pelo ato de "prometer", o sujeito pretende legitimar seu discurso enquanto verdadeiro, pois o lugar de onde fala não Ihe

\footnotetext{
${ }^{4} \mathrm{Na}$ música "Lei da sobrevivência" (O Rappa), uma das possíveis interpretações é a crítica que se faz acerca das questões políticas e desigualdades sociais especialmente nos versos: "Eu não quero ficar/esperando/o tempo passar, passar/ Quem colhe, quem planta/ também tem direito de comer/ e comer bem/ A comida melhor está na cidade/ dentro do armazém/ Estragando só pro povo ter/ consciência/ que a lei da sobrevivência/ é votar e não comer". Entretanto, no contexto desse discurso, o "ficar esperando" de que se refere, pode ser uma crítica à prisão, pois é nesse local que fica esperando o tempo passar, e sua liberdade depende do outro. Disponível em <http://www.vagalume.com.br/o-rappa/leida-sobrevivencia.html>Acesso em: 22/05/13.

${ }^{5}$ Essa expressão é comumente usada para referir-se à prisão. Esse dizer é também presente na música "Aonde o fillho chora e a mãe não vê" (Facção Central), que apresenta uma crítica à prisão, ao governo, trazendo cenas de rebelião e disputas entre facções criminosas inimigas: "Ratatá, ratatá, o sangue vai escorrer/Aqui é onde o filho chora bum e a mãe não vê". (Disponível em: < http://letras.mus.br/faccao-central/787137/>). Acesso em: 31/07/2013.
} 


\section{Revista do SELL}

v. $4, n^{\circ} .1$

ISSN: $1983-3873$

propicia tal merecimento, e, em consonância com os condenados que deveriam jurar dizer somente a verdade, em seu discurso faz-se necessária a promessa de que é verdadeiro, para que tenha voz, tenha vez.

Atentando-nos para um item lexical bastante recorrente, o "mas", ressaltamos que o recorte selecionado para esta análise decorre de uma carta de quatro páginas escritas, possuindo um totalizante de doze utilizações dessa conjunção coordenativa adversativa. Não nos interessa tal recorrência em cunho quantitativo, mas em face de considerarmos aqui, as regularidades imersas nesse discurso. No referido recorte, as frases estão concentradas em parágrafo único e há utilização da conjunção "mas" por sete vezes ${ }^{6}$, o que marca nessa regularidade as contradições pelas quais o sujeito constrói sua identidade, e em Neves (2000, p.756), "o MAS evidencia exterioridade entre os dois segmentos coordenados e, a partir daí, coloca o segundo segmento como de algum modo diferente do primeiro, especificando-se essa desigualdade conforme as condições contextuais".

Nesse recorte, interpretamos que o sujeito busca "ceder" ao que é proposto, na tentativa de dizer somente o que pode ser dito. Porém, tratando-se de um sujeito inconsciente, essa tentativa falha, havendo lapsos que deslizam entre as marcas de subjetividade, emergindo nesse contexto, discursos da estratégia e da resistência, confirmando nossa hipótese de pesquisa de que, pela exposição da subjetividade, as mulheres internas silenciam, mas tratando-se de um sujeito inconsciente, cindido e clivado, os efeitos de sentido deslizam, fogem do controle. Isso porque, "o discurso é sempre incompleto assim também como são incompletos os sujeitos e os sentidos" (ORLANDI, 2008. p.113). Em sua escrita pede pela presença do outro. Pede para ser lembrado. Constitui sua identidade. Busca constituir-se. E o faz no/pelo olhar do outro.

Logo, o sujeito da carta (01), que nesse recorte analisamos (recorte 01), mostra-se por uma imagem criada a partir da representação que acredita que o outro tenha sobre ele, isto é, uma imagem não positiva: a de não merecedor - das cartas, das visitas, das lembranças... Nesse momento, deixa (des)velar o sujeito fragmentado que é, pois o discurso do outro passa a ser o seu discurso; ainda que "(in)diretamente", utiliza-se das palavras do outro numa suposta concordância, quando na verdade deseja livrar-se desse pré-conceito. Logo, o discurso do sujeito da carta (01) é interpelado pelo discurso do

\footnotetext{
${ }^{6}$ Vale ressaltar aqui, que uma análise mais detalhada acerca das diferentes funções que a conjunção adversativa "mas" assume nesse discurso encontra-se na dissertação de Mestrado já citada, mas que aqui, por falta de espaço, não desenvolveremos.
} 


\title{
Revista do SELL \\ v. $4, n^{\circ} .1$
}

ISSN: $1983-3873$

outro, uma vez que é heterogêneo. Por fim, pela noção foucaultiana de "relações de poder" (FOUCAULT, 1979), nota-se o poder em circulação, uma vez que ainda que esteja regulado pelos dispositivos de controle, o discurso dessa mulher interna - via escrita de si - denuncia a impossibilidade da dicotomia "opressor vs. oprimido", uma vez que emerge, por meio de um jogo estratégico, a imagem que deseja que o outro tenha dela e, assim, representa-se enquanto arrependida, recuperada, injustiçada, a fim de que sua voz tenha vez.

\begin{abstract}
Recorte (2):
Salve salve cunhado pelo jeito ta FMZ pra ti ne? Ainda bem porque cadeia é osso muito, sofrimento mais é nois pode crê. [...] ja até sei falar na gira kkkk [...] $(\mathrm{D})$ mudando de assunto" Salve salve ainda bem que você deu um jeitinho na $(T)$ e que ela não compareça no forum cadeia não é perpetua um dia saimos [...] as vezes bate um desespero principalmente dia de Domingo é osso mas tudo bem quando sairmos daqui vamos continuar. É nois na fita sempre fomos forte não é agora que vamos fraquejar.

(D) fica Com Deus.

Retorne
\end{abstract}

Sem data para não virar passado

(Carta 2)

A saudação inicial é nesse discurso marcada por um dizer cristalizado, o clichê "salve salve", que em outro momento da carta, marca uma mudança de assunto onde, novamente o sujeito cumprimenta o destinatário por esse dizer. Ainda, sua escrita possui marcas linguísticas de gírias, e segundo Ferreira (2000, p. 348) as gírias podem significar "linguagem de malfeitores, malandros, etc.; linguagem que, nascida em certo grupo social, termina estendendo-se à linguagem familiar". Assim, o sujeito utiliza as seguintes gírias: "é osso", "é nois pode crê", "é nois na fita", "ta FMZ pra ti ne?", entre outras ${ }^{8}$, bem como o dizer: "já até sei falar na gira kkkk". Nesse dizer, os advérbios "já até" funcionam como "advérbios de inclusão" (NEVES, 2000, p. 240), e nesse caso, deslocam o sentido do verbo "saber" em: "sei falar na gira".

Isso porque, nesse dizer o verbo "saber" funciona como uma marca identitária, de identificação a um saber pelo qual busca seu sentimento de pertença a um grupo. Segundo Coracini (2007, p. 51), "constituído na e pela falta, o sujeito (se) constrói uma identidade (que ele crê transparente), constrói sua morada para nela habitar, na ilusão de, assim, poder se definir (identificar-se a si próprio), se encontrar com o outro (identificar-se

\footnotetext{
${ }^{7}$ Significado: “[...] pode ser definido como um apenas Firmeza (para maloqueiro) ou Beleza (para os cultos) e até mesmo já é (para os cariocas)". Disponível em: <http://www.dicionarioinformal.com.br/salve/>. Acesso em: 30/07/2013.

${ }^{8}$ Em outros momentos da carta, o sujeito escreve: "sou o homenzinho do Barraco”, “nossa cela é de Boa”, "só cascuda e jegua velha”, "aqui fazemos o corre”.
} 


\section{Revista do SELL \\ v. $4, n^{\circ} .1$ \\ ISSN: $1983-3873$}

ao outro)". Assim, o "saber falar na gíria", constitui o processo de construção de sua identidade, pois o sujeito acredita que se tornando semelhante a esse grupo que fala de um modo específico, encontra o outro, é semelhante, é pertença.

Nesse tocante, a representação de cadeia enquanto "sofrimento" emerge no discurso uma representação identitária de submissão, inicialmente. Considerando, contudo, que "dentro de nós há identidades contraditórias, empurrando em diferentes direções [...]" (HALL, 2005, p.13), o sujeito transita entre as representações de identidade, deslocando-se da submissão à fortaleza e à resistência. Trata-se do poder, pois continua liderando, ainda que se veja no sofrimento que descreve.

Assim, seu discurso é inicialmente de submissão, já que se vê "controlada" em vários momentos, como em: "cadeia é osso muito, sofrimento", e "as vezes bate um desespero". Contudo, esse discurso é ao mesmo tempo de resistência, pois há a tentativa de mostrar sua autossuficiência, e por sua vez, de liderança pelos dizeres: "mais é nois pode crê", "cadeia não é perpétua um dia saímos", "quando sairmos daqui vamos continuar", "é nois na fita", "sempre fomos forte" e "não é agora que vamos fraquejar". A esse respeito, segundo Foucault (2006a, p. 232), "as relações de poder suscitam necessariamente, apelam a cada instante, abrem a possibilidade a uma resistência". Nesse tocante, esses dizeres corroboram para o sentido de que não há poder absoluto, não há poder sem resistência. Logo, a constituição da identidade desse sujeito se dá em meio às relações de poder, e esses dizeres produzem o efeito de sentido de que se representa pelo discurso da resistência para desconstruir uma representação identitária de submissão, buscando em seu discurso, passar a imagem de uma mulher segura, resistente, forte.

Ainda, o uso da 3모 pessoa do plural nas marcas verbais: "saimos", "sairmos", "vamos", "fomos" e "vamos" inclui as outras mulheres internas na constituição de sua identidade, o que produz o efeito de sentido de que o sujeito busca constituir-se no/pelo olhar do outro e com ele identificar-se. Segundo Coracini (2003, p. 151), "não podemos acreditar na possibilidade de uma identidade acabada, descritível; só podemos postular momentos de 'identificação' em movimento constante e em constante modificação”. Assim, em face de considerarmos o sujeito como cindido e descentrado, habitado pelo outro, nesses dizeres o sujeito busca sua identificação ao outro no processo de construção de sua identidade.

Logo, o sujeito desloca-se pelo olhar que faz sobre si mesmo e sobre o outro em diferentes marcas identitárias, e nesse sentido, ora representa-se enquanto submisso, ora 


\section{Revista do SELL}

v. $4, n^{\circ} .1$

ISSN: $1983-3873$

enquanto resistente e forte, onde o advérbio "quando", em: "quando sairmos daqui vamos continuar" marca o sentido de retorno à fortaleza fora da prisão, usando o dêitico "daqui" para referir-se a esse lugar de onde fala. Já os advérbios temporais "sempre" e "agora", em: "sempre fomos forte não é agora que vamos fraquejar" separam o antes e o depois da prisão, produzindo o efeito de sentido de que este lugar atravessa a constituição de sua identidade.

Nesse dizer, diferentes vozes constituem o sujeito e seu discurso, pois precisa negar que é fraca (discurso que possivelmente é do outro) para afirmar que é forte (desejo reprimido de ser forte). O sujeito traz o outro para o seu discurso, pois é esse o lugar da alteridade. Pela denegação, responde, rebate, resiste. Segundo Eckert-Hoff (2003, p. 290-291), "a denegação revela, embora tente camuflar, o que é e não é dito ao mesmo tempo", e ainda, "o escopo da denegação é o discurso do outro: ela mascara a voz do outro, outras vozes, que, inconscientemente, atravessam o dizer do sujeito" ( $p$. 291). Assim, os opostos "ser forte/ser fraca", constituem uma ruptura no fio discursivo, que é atravessado pelo discurso-outro na denegação.

Nesse tocante, quando precisa afirmar que "sempre foram fortes" seu discurso traz o que realmente deseja e assim, "pela denegação, o sujeito expressa uma resistência regida pela censura, enunciando uma verdade reprimida" (ECKERT-HOFF, 2008, p. 97). Essas diferentes vozes desestabilizam as representações cristalizadas e o sujeito, por meio da denegação, transita entre esses pontos de identificação, ora entre o ser "forte" (desejo que manifesta), ora entre o ser "fraca" (discursos instituídos). Eckert-Hoff (2003, p. 293) diz que a denegação é a "marca que evidencia o não-um no tecido do dizer". Ainda, o sujeito fala pela voz do Outro, pois no sentido lacaniano, "a denegação é regida sempre pelo discurso do Outro. O sujeito não tem acesso à própria enunciação, senão por meio da negativa que lhe dá a ilusão da lógica, marcando o retorno do recalcado" (ECKERTHOFF, 2008, p. 98). Assim, quando o sujeito nega que é fraco, o faz no desejo de ser forte, pensando ter domínio sobre aquilo que diz, e nesse sentido, "é na ilusão do domínio da linguagem e dos sentidos que o inusitado irrompe" (p. 98). Assim, pela da denegação, embora que de modo camuflado, o sujeito revela ao mesmo tempo o que é e o que não é dito.

Interessante observar que ao escrever: "cadeia não é perpetua” há ainda um nãodito que produz um sentido significativo. Na esteira do que diz Orlandi (2007, p. 73), "o silêncio constitutivo pertence à própria ordem de produção do sentido", o que produz sentidos entre o que se diz e o que não se diz. No contexto desse discurso, ao dizer: 


\section{Revista do SELL}

v. $4, n^{\circ} .1$

ISSN: $1983-3873$

“cadeia não é perpetua", pelo advérbio de negação "não" o sujeito está silenciando o dizer: "cadeia é perpétua", e esse, constitui o sentido descartado pelo dito, isso porque, tratando-se da prisão, o sujeito é supostamente controlado. Nesse caso, essa forma de silêncio é "o mecanismo que põe em funcionamento o conjunto do que é preciso não dizer para poder dizer" (p. 74). Segundo a autora, é nessa forma de silêncio que se apagam os sentidos que se quer evitar, pois esses, emergem significações que podem vir de outras formações discursivas e outras regiões de sentido. Assim, esse silenciamento produz o efeito de sentido de que o sujeito, ao apagar um sentido para produzir outro, fala a partir do que pode ou não dizer na prisão, pois passa por um sistema de controle e vigilância.

Por fim, em: "sem data para não virar passado", o sujeito deseja manter viva a sua escrita. O verbo "virar" produz o sentido que a data fixa, imobiliza, torna passado o que pode ser um presente contínuo. Assim, o sujeito, sem marcar a data, deseja (re)viver pela escrita. Inscrever-se na folha, na memória, em si, no outro. Uma data marca um tempo, um momento. Uma data marca uma história. Uma data compromete. Fixa um período. Delimita um acontecimento. O sujeito ata em seu texto um fio que o permite que não seja somente uma lembrança, um passado. Assinar sem data, é movimentar-se no tempo. É poder ser ontem, hoje e amanhã. É transitar pela história. É recusar-se à estabilidade. Skliar (2008, p. 13) coloca no sentido derridiano que: "a data, as datas devem permanecer tanto legíveis quanto ilegíveis, tanto de alguém como de ninguém”.

Nesse recorte, pela escrita, o sujeito busca sua identificação. Identificação essa que se dá pelo seu olhar sobre si, sobre o outro. No desejo da completude, assemelha-se e distancia-se. Assume e resiste. Afirma e nega. É sujeito. Pela escrita se constitui. Deixa marcas de subjetividade. Transita em seu processo de construção da identidade. Desloca. $(\mathrm{Re})$ configura identificações. Fala de um grupo. Assemelha-se a uns. Diferencia-se de outros. Incessante busca de completude. Incessante processo de (des)construção. Desestabilização. Jogo de semelhanças e diferenças. Resistência. Identidade. Subjetividade. Assina sem data. É presente. É futuro. Mas não quer ser um simples passado. Pelas relações de poder, representa-se enquanto forte e, assim, consegue sair dessa "prisão perpétua" em que se encontra.

\section{Considerações finais}

Por meio de gestos de interpretação diferentes efeitos de sentido emergiram na escrita das cartas das mulheres detentas, que em seu discurso se veem por 


\section{Revista do SELL \\ v. $4, n^{\circ} .1$ \\ ISSN: $1983-3873$}

representações identitárias que se (des)constroem no/pelo olhar do outro. Pudemos refletir que ilusão seria pensar que vozes supostamente silenciadas se rendem às tentativas de dominação, pois, uma vez revestido de ideologia, poder e, sobretudo, subjetividade, o discurso daqueles que por vezes, são tomados enquanto silenciados não aplaude a submissão, mas emerge enfim, sob os percalços de uma inquietante resistência, o que confirma a nossa hipótese de investigação. Tais enredos nos encorajam a investigar os tácitos processos que entrelaçam identidade, poder e exclusão, uma vez que há uma possível (des)construção das representações de identidade em meio às tentativas de silenciamento.

Contrários às representações imaginárias que, por vezes, determinam as detentas enquanto frágeis e passíveis ao sistema de controle emergem discursos que caracterizam esse contexto enquanto espaço de luta e confronto, uma vez que em sua escrita resistem às representações identitárias a elas direcionadas pelos discursos da resistência e da estratégia.

A análise mostra que as representações de identidade das mulheres detentas do Presídio Feminino de Três Lagoas - MS são atravessadas pelo outro, uma vez que em seu discurso se veem em confronto com pré-julgamentos que se fazem em meio ao cotidiano, onde discursos cristalizados julgam o que é correto, homogeneizando (e excluindo) os sujeitos que, porventura, não cumpriram os tratos sociais, e que, portanto, devem ser corrigidos e transformados. Pela análise, notamos que a identidade dessas mulheres internas é multifacetada, em processo, e, sobretudo, constituída no/pelo olhar do outro, e nesse sentido, transitam estrategicamente em diferentes representações, que ora as posicionam enquanto submissas, ora enquanto resistentes.

Assim, esse espaço de privação de liberdade vai além dos muros circundantes do Presídio, pois extrapola os limites e suas demarcações, uma vez que nesse contexto emergem discursos que tratam de um sistema de controle não só corporal, mas, sobretudo, ideológico. Entretanto, pelo poder que atravessa e constitui o discurso enquanto instrumento de poder, os muros que buscam silenciar são chocados com a resistência, e assim, os sujeitos constroem sua identidade. Confrontam. Resistem. Vão do silenciamento à resistência. Resistência à exclusão pelo poder do seu discurso. E este, é luta. É poder. É prática social. 


\section{Revista do SELL}

v. $4, n^{\circ} .1$

ISSN: $1983-3873$

\section{Referências}

AUTHIER-REVUZ. Palavras incertas: as não-coincidências do dizer. Campinas: Editora da UNICAMP, 1998.

BRASIL. Senado Federal. Lei n. 7.210/84. Lei de Execução Penal. Brasília: Senado Federal, 2009.

CORACINI, M. J. R. F. (Org). Identidade \& discurso: (des)construindo subjetividades. Campinas: Editora da UNICAMP; Chapecó: Argos Editora Universitária, 2003.

A celebração do outro: arquivo, memória e identidade: línguas (materna e estrangeira), plurilinguismo e tradução. Campinas, SP: Mercado de Letras, 2007.

ECKERT-HOFF, B. M. A denegação como possibilidade de "captura" do não-um no tecido do dizer. In: CORACINI, M.J.R.F. Identidade e discurso: (des)construindo subjetividades. Campinas: Editora da UNICAMP; Chapecó: Argos Editora Universitária, 2003. p. 285-302.

Escritura de si e identidade: o sujeito-professor em formação. Campinas: Mercado de Letras, 2008.

FERREIRA, A. B. H. Miniaurélio Século XXI Escolar: O minidicionário da língua portuguesa. Coordenação de edição Margarida dos Anjos, Marina Baird Ferreira; Lexicografia Margarida dos Anjos... [et al.] 4. ed. rev. Ampliada. Rio de Janeiro: Nova Fronteira, 2000.

FOUCAULT, M. Microfísica do poder. Trad e Org. de Roberto Machado. Rio de Janeiro: Edições Graal, 1979.

. A ordem do discurso. Tradução de Laura Fraga de Almeida Sampaio. 20. Ed. São Paulo: Loyola, 1995.

1926-1984. Estratégia, poder-saber. (Coleção: Ditos e Escritos IV). Michel Foucault: organização e seleção de textos, Manoel Barros da Motta: tradução, Vera Lucia Avellar Ribeiro. 2. ed. Rio de Janeiro: Forense Universitária, 2006a.

1983. A escrita de si. In: FOUCAULT, M. 1926-1984. Ética, sexualidade, política. (Coleção: Ditos e Escritos V). Organização e seleção de textos Manoel Barros da Motta; tradução Elisa Monteiro, Inês Autran Dourado Barbosa. 2.ed. Rio de Janeiro: Forense Universitária, 2006b. p. 144-162.

1926-1984. Ética, sexualidade, política. (Coleção: Ditos e Escritos V). Organização e seleção de textos Manoel Barros da Motta; tradução Elisa Monteiro, Inês Autran Dourado Barbosa. 2.ed. Rio de Janeiro: Forense Universitária, 2006c.

Repensar a política. (Coleção: Ditos e Escritos VI). Tradução Ana Lúcia Paranhos Pessoa; Organização e seleção de textos: Manoel Barros da Motta. Rio de Janeiro: Forense Universitária, 2010a. 


\section{Revista do SELL}

v. $4, n^{\circ} .1$

ISSN: $1983-3873$

. Em defesa da sociedade: curso no Collège de France (1975-1976). Tradução Maria Ermantina Galvão. 2. ed. São Paulo: Editora WMF Martins Fontens, 2010b.

Vigiar e punir: nascimento da prisão. Trad. de Raquel Ramalhete. 40. ed. Petrópolis: Vozes, 2012.

HALL, S. A identidade cultural na pós-modernidade. Trad. de Tomaz T. da Silva e Guaciara L. Louro. 10. ed. Rio de Janeiro: São Paulo: DP \& A, 2005.

NEVES, M. H. de M. Gramática de usos do português. 6. reimpressão. São Paulo: Editora da UNESP, 2000.

ORLANDI, E. P. As formas do silêncio: no movimento dos sentidos. 6. ed. Campinas: Editora da Unicamp, 2007.

Discurso e Texto: formulação e circulação dos sentidos. 3. ed. Campinas: Edição Pontes Editores, 2008.

REIS, V. S. O ensino-aprendizagem do inglês como língua estrangeira (ILE) no espaço dentro-fora da lei de uma Unidade Socioeducativa para adolescentes infratores. 2011. 266 f. Tese (Doutorado em Linguística Aplicada) - Programa de Pós-Graduação Stricto Sensu em Estudos Linguísticos, Faculdade de Letras da Universidade Federal de Minas Gerais, Belo Horizonte, 2011.

SAWAIA, B. (Org.) (et al). As artimanhas da exclusão: análise psicossocial e ética da desigualdade social. 2. ed. Rio de Janeiro: Vozes, 2001.

SKLIAR, C. A escrita na escrita: Derrida e Educação. In: (Org.). Derrida \& a Educação. Belo Horizonte: Autêntica, 2008. p. 9-33. 